\title{
AKTIVITAS ANTIBAKTERI GEL EKSTRAK KECOMBRANG (ETLINGERA ELATIOR) TERHADAP BAKTERI STAPHYLOCOCCUS AUREUS DAN STAPHYLOCOCCUS EPIDERMIDIS
}

\author{
Yosefin Ida Saptana, Riski Sulistiarini, Rolan Rusli \\ Laboratorium Penelitian dan Pengembangan FARMAKA TROPIS, Fakultas Farmasi, \\ Universitas Mulawarman, Samarinda, Kalimantan Timur \\ Email:iiosi_enn@yahoo.co.id
}

\begin{abstract}
Antibacteria gel is a semisolid form that is clear, transparent and consist of active substance which is a colloid dispersion that has a power which is caused of intertwined tissues on dispersion phase, that can hamper or destroy bacteria. Etlingera elatior, is a plant that is used by people to remove mouth and body odour. The purpose of this research is to find out the activity of antibacteria gel from the methanol extract of Etlingera elatior towards Staphylococcus aureus bacteria and Staphylococcus epidermidis bacteria. The extract used is a methanol extract that is obtained from the extraction process with maceration method. Agar Diffusion method is used on the test with the concentration of the extracts are $4 \%, 5 \%$ and $6 \%$. The result of this observation shows that methanol extract gel of Etingera elatior possess the antibacteria activity towards Staphylococcus aureus dan Staphylococcus epidermidis.
\end{abstract}

Key Words: Etlingera elatior, Gel, Antibacteria Activity, Agar Diffusion Test, Staphylococcus aureus, Staphylococcus epidermidis

\begin{abstract}
ABSTRAK
Sediaan gel antibakteri umumnya merupakan suatu sediaan semipadat yang jernih, tembus cahaya dan mengandung zat aktif, merupakan dispersi koloid mempunyai kekuatan yang disebabkan oleh jaringan yang saling berikatan pada fase terdispersi, yang dapat menghambat atau membunuh bakteri. Bunga kecombrang (Etlingera elatior) merupakan tanaman yang digunakan masyarakat sebagai penghilang bau mulut dan penghilang bau badan. Penelitian ini bertujuan untuk mengetahui aktivitas antibakteri sediaan gel dari ekstrak metanol bunga kecombrang (Etlingera elatior) terhadap bakteri Staphylococcus aureus dan Staphylococcus epidermidis. Ekstrak yang digunakan merupakan ekstrak metanol yang diperoleh melalui proses ekstraksi dengan metode maserasi. Uji aktivitas dilakukan dengan menggunakan metode difusi agar dengan konsentrasi ekstrak ialah 4\%, $5 \%$, dan 6\%. Hasil penelitian menunjukkan gel ekstrak metanol bunga kecombrang memiliki aktivitas antibakteri terhadap bakteri Staphylococcus aureus dan Staphylococcus epidermidis.
\end{abstract}

Kata kunci: Bunga Kecombrang, gel, aktivitas antibakteri, Difusi agar, Staphylococcus aureus, Staphylococcus epidermidis

\section{PENDAHULUAN}

Kecombrang (Etlingera elatior) merupakan Salah satu tanaman rempah dan obat yang memiliki potensi sebagai pangan fungsional yang berfungsi sebagai antibakteri. 
Bunga dari tanaman ini bisa digunakan sebagai bahan kosmetik alami dimana bunganya dipakai untuk campuran cairan pencuci rambut dan daun serta rimpangnya dipakai untuk bahan campuran bedak oleh penduduk lokal [1]. Hal ini karena pada bunga kecombrang memiliki senyawa metabolit sekunder seperti alkaloid, flavonoid, polifenol, terpenoid, steroid, saponin, dan minyak atsiri [2]. Dengan adanya kandungan metabolit sekunder yang aktif sebagai antibakteri menjadikan bunga kecombrang berpotensi untuk dikembangkan sebagai bahan aktif dalam berbagai produk obat-obatan dan kosmetik. Produk obat-obatan dan kosmetik antibakteri tersebut dapat diformulasi dalam bentuk sedian gel. Oleh karena itu, penelitian ini dilakukan untuk menentukan aktivitas antibakteri sedian gel ekstrak bunga kecombrang.

\section{METODE PENELITIAN}

\section{Bahan}

Bahan yang digunakan dalam penelitian ini adalah simplisia bunga kecombrang, metanol, paper disc, medium NA (Nutrient Agar), $\mathrm{NaCl}$ 0,9\%, Na-CMC, Gliserin, Propilenglikol, metilparaben, propilparaben, dan air suling.

\section{Peralatan}

Peralatan yang digunakan dalam penelitian ini adalah wadah maserasi, rotary evaporator, waterbath, timbangan analitik, cawan porselin, labu ukur, gelas kimia, tabung reaksi, micropipet, labu erlenmeyer, gelas ukur, autoklaf, inkubator, cawan petri, spoit injeksi, LAF (Laminar Air Flow), mikrometer sekrup, dan alat penunjang lain.

\section{Prosedur Penelitian}

Bunga kecombrang diperoleh dari kota Samarinda, Kalimantan Timur, dikumpulkan kemudian disortasi dan dipotong kecil-kecil serta dikeringkan. Bunga kecombrang kering selanjutnya diekstraksi dengan metode maserasi menggunakan pelarut metanol, hingga diperoleh maserat, yang selanjutnya diuapkan pelarutnya hingga diperoleh ekstrak kental. Ekstrak yang diperoleh selanjutnya diformulasi dengan berbagai komponen lain, yang dirangkum dalam Tabel 1. Pembuatan gel dilakukan dengan terlebih dahulu metilparaben dan propil paraben dilarutkan dalam air suling yang telah dipanaskan, kemudian ditambahkan ekstrak metanol bunga kecombrang. Selanjutnya ditambahkan Na CMC dan diaduk hingga homogen lalu ditambahkan gliserin dan propilenglikol.

Tabel 1. Formula gel ekstrak metanol bunga kecombrang

\begin{tabular}{lcccc}
\hline \multirow{2}{*}{ Nama Bahan } & \multicolumn{5}{c}{ Konsentrasi (\%) } \\
\cline { 2 - 5 } & $\mathbf{F}_{\mathbf{0}}$ & $\mathbf{F}_{\mathbf{1}}$ & $\mathbf{F}_{\mathbf{2}}$ & $\mathbf{F}_{\mathbf{3}}$ \\
\hline Ekstrak kecombrang & 0 & 4 & 5 & 6 \\
Gliserin & 12 & 12 & 12 & 12 \\
Metilparaben & 0,15 & 0,15 & 0,15 & 0,15 \\
Na CMC & 4 & 4 & 4 & 4 \\
propilenglikol & 4 & 4 & 4 & 4 \\
Propilparaben & 0,03 & 0,03 & 0,03 & 0,03 \\
Air suling & ad $100 \%$ & ad $100 \%$ & ad $100 \%$ & ad $100 \%$ \\
\hline
\end{tabular}




\section{Pengujian Aktivitas Antibakteri}

Proses awal yang dilakukan adalah membuat medium NA dengan cara melarutkan 5 gram bubuk NA dalam $250 \mathrm{~mL}$ air suling kemudian diaduk dan dipanaskan hingga larut. Selanjutnya medium yang telah dibuat dan alat-alat yang akan digunakan disterilkan dengan autoklaf pada suhu $121{ }^{\circ} \mathrm{C}$. Bakteri uji ditanamkan di atas permukaan agar miring yang telah memadat dalam tabung reaksi dan diinkubasi pada inkubator selama 24 jam pada suhu $37{ }^{\circ} \mathrm{C}$. Setelah 24 jam, dibuat suspensi bakteri dengan menambahkan $\mathrm{NaCl}$ $0,9 \%$ hingga diperoleh pengenceran 1:40.

Pengujian aktivitas antibakteri gel ekstrak metanol bunga kecombrang dilakukan dengan metode difusi agar. Suspensi bakteri 1:40 sebanyak 0,02 mL dimasukkan kedalam cawan petri dan ditambahkan dengan $10 \mathrm{~mL}$ medium NA lalu dihomogenkan, dengan cara menggoyang cawan petri. Ditunggu beberapa saat hingga medium setengah padat. Setelah itu paper disc yang telah direndam dalam masing-masing formula diletakkan di atas permukaan medium NA. Kemudian diinkubasi pada suhu $37{ }^{\circ} \mathrm{C}$ selama 24 jam. Kontrol negatif digunakan paper disc yang telah direndam dalam basis gel.

\section{HASIL DAN PEMBAHASAN}

Formulasi gel dibuat sebanyak 4 formula. Yang berbeda dari keempat formula tersebut ialah konsentrasi ekstrak metanol bunga kecombrang. Formula gel terdiri dari ekstrak metanol bunga kecombrang, $\mathrm{NaCMC}$, propilparaben, metilparaben, propilenglikol, dan gliserin. Ekstrak metanol bunga kecombrang berfungsi sebagai zat aktif. NaCMC berfungsi sebagai gelling agent yang merupakan bahan pembentuk gel. Propilenglikol berfungsi sebagai humektan yang akan menjaga kestabilan sediaan dengan cara mengasorbsi lembab dari lingkungan dan mengurangi penguapan air dari sediaan. Selain itu, humektan juga dapat mempertahankan kelembaban kulit sehingga kulit tidak kering [4]. Metilparaben dan propilparaben berfungsi sebagai pengawet [5]. Pengawet diperlukan dalam formulasi gel karena gel memiliki kandungan air yang tinggi sehingga dapat menyebabkan terjadinya kontaminasi mikroba. Air suling berfungsi sebagai pelarut dalam formulasi gel [6].

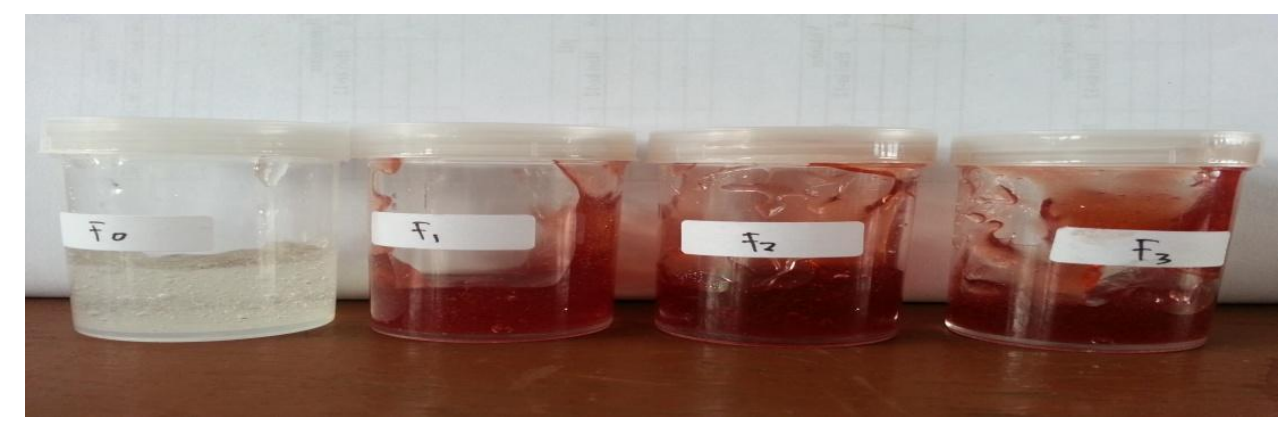

Gambar 1. Basis gel $\left(\mathrm{F}_{0}\right)$, gel ekstrak metanol bunga kecombrang $4 \%\left(\mathrm{~F}_{1}\right)$, gel ekstrak metanol bunga kecombrang $5 \%\left(\mathrm{~F}_{2}\right)$, gel ekstrak metanol bunga kecombrang $\left(\mathrm{F}_{3}\right)$.

Pengujian aktivitas antibakteri gel ekstrak metanol bunga kecombrang terhadap bakteri Staphylococcus aureus dan Staphylococcus epidermidis menggunakan 4 formula, yaitu $0 \%, 4 \%, 5 \%$, dan 6\%. Pengujian dilakukan dengan 3 replikasi. Hasil pengujian aktivitas antibakteri gel ekstrak metanol bunga kecombrang dapat dilihat pada Gambar 2. 

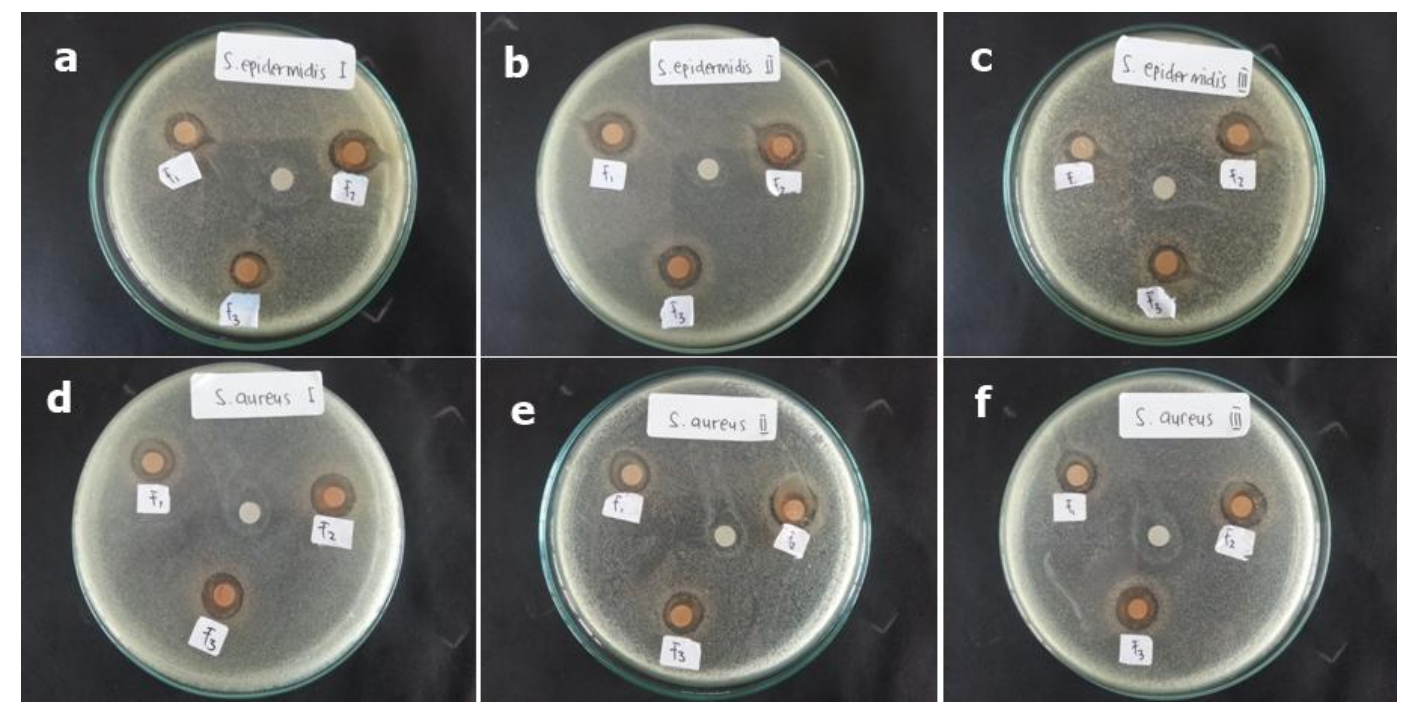

Gambar 2. Uji aktivitas antibakteri gel ekstrak metanol bunga kecombrang terhadap bakteri (a, b, dan c) Staphylococcus aureus dan (d, e dan f) Staphylococcus epidermidis

Gambar 2 menunjukkan adanya aktivitas antibakteri gel ekstrak metanol bunga kecombrang terhadap bakteri Staphylococcus aureus dan Staphylococcus epidermidis. Kontrol negatif yaitu basis gel yang tidak diberikan zat aktif. Kontrol negatif tidak menunjukkan adanya zona hambat maupun zona bunuh disekitar paper disc, sehingga dapat disimpulkan bahwa aktivitas antibkteri berasal dari zat aktif yang merupakan ekstrak metanol bunga kecombrang bukan dari basis gel. Pada gambar juga terlihat adanya perbedaan zona bening pada setiap konsentrasi gel ekstrak metanol bunga kecombrang.

Data yang menunjukkan zona bunuh yang terbentuk dari hasil aktivitas antibakteri gel ekstrak metanol bunga kecombrang terhadap bakteri uji dapat terlihat pada tabel 2.

Tabel 2. Data aktivitas antibakteri gel ekstrak metanol bunga kecombrang

\begin{tabular}{cccc}
\hline \multirow{2}{*}{ Sampel Uji } & \multirow{2}{*}{ Konsentrasi } & \multicolumn{2}{c}{ Rerata Diameter Zona Bunuh (mm) } \\
\cline { 3 - 4 } & & Staphylococcus aureus & Staphylococcus epidermidis \\
\hline Gel Ekstrak & $0 \%$ & - & - \\
Metanol & $4 \%$ & 4,67 & 4,01 \\
Bunga & $5 \%$ & 5,52 & 4,93 \\
Kecombrang & $6 \%$ & 5,01 & 3,71 \\
\hline
\end{tabular}

Menurut Davis and Stout (1971) dalam mpila [7], kriteria kekuatan daya antibakteri sebagai berikut: diameter zona hambat $5 \mathrm{~mm}$ atau kurang dikategorikan lemah, zona hambat 5-10 mm dikategorikan sedang, zona hambat 10-20 mm dikategorikan kuat dan zona hambat $20 \mathrm{~mm}$ atau lebih dikategorikan sangat kuat. Berdasarkan kategori tersebut dapat disimpulkan bahwa gel ekstrak metanol bunga kecombrang dengan konsentrasi $4 \%$ memiliki aktivitas antibakteri yang lemah terhadap kedua bakteri uji. Sedangkan gel ekstrak metanol dengan konsentrasi 5 dan 6 persen memiliki aktivitas dalam kategori 
sedang terhadap bakteri Staphylococcus aureus dan aktivitas yang lemah terhadap bakteri Staphylococcus epidermidis.

\section{Analisis Statistik Aktivitas Antibakteri}

Tabel 3. Uji Normalitas Zona Bunuh Gel Ekstrak Metanol Bunga Kecombrang terhadap Bakteri Staphylococcus aureus dan Staphylococcus epidermidis.

\begin{tabular}{lllccc}
\hline & Bakteri uji & & \multicolumn{3}{c}{ Shapiro-Wilk } \\
\cline { 3 - 6 } & & Konsentrasi & Statistik & Df & Sig. \\
\hline Diameter & Staphylococcus & $4 \%$ & .991 & 3 & .821 \\
& aureus & $5 \%$ & .983 & 3 & .753 \\
& $6 \%$ & .780 & 3 & .069 \\
\cline { 2 - 5 } & Staphylococcus & $4 \%$ & .990 & 3 & .806 \\
& epidermidis & $5 \%$ & .992 & 3 & .831 \\
& $6 \%$ & .779 & 3 & .066 \\
\hline
\end{tabular}

Tabel 4. Uji Homogenitas Zona Bunuh Gel Ekstrak Metanol Bunga Kecombrang terhadap Bakteri Staphylococcus aureus dan Staphylococcus epidermidis.

\begin{tabular}{lcccc}
\hline \multicolumn{1}{c}{ Bakteri uji } & $\begin{array}{c}\text { Uji } \\
\text { Levene }\end{array}$ & df1 & df2 & Sig. \\
\hline Staphylococcus aureus & 2.557 & 2 & 6 & .157 \\
Staphylococcus epidermidis & 1.687 & 2 & 6 & .262 \\
\hline
\end{tabular}

Tabel 5. Uji Anava Zona Bunuh Gel Ekstrak Metanol Bunga Kecombrang terhadap Bakteri Staphylococcus aureus dan Staphylococcus epidermidis.

\begin{tabular}{|c|c|c|c|c|c|c|}
\hline Bakteri Uji & & Jumlah Kuadrat & df & Rerata Kuadrat & F & Sig. \\
\hline \multirow{2}{*}{$\begin{array}{c}\text { Staphylococcus } \\
\text { aureus }\end{array}$} & Perlakuan & 1.102 & 2 & .551 & .476 & .643 \\
\cline { 2 - 7 } & Galat & 6.943 & 6 & 1.157 & & \\
\cline { 2 - 7 } & Total & 8.046 & 8 & & & \\
\hline \multirow{2}{*}{$\begin{array}{c}\text { Staphylococcus } \\
\text { epidermidis }\end{array}$} & Perlakuan & 2.357 & 2 & 1.178 & 3.650 & .092 \\
\cline { 2 - 7 } & Galat & 1.937 & 6 & .323 & & \\
\cline { 2 - 7 } & Total & 4.294 & 8 & & & \\
\hline
\end{tabular}

Berdasarkan tabel normalitas dapat dilihat pada tabel signifikan. Jika nilai signifikan $>0,05$ maka sampel berasal dari populasi yang berdistribusi normal, sedangkan jika nilai signifikan $<0,05$ maka sampel bukan berasal dari populasi berdistribusi normal. Pada tabel diatas dapat dilihat nilai signifikansi semua sampel > 0,05 maka dapat disimpulkan semua sampel berasal dari populasi yang berdistribusi normal.

Uji homogenitas dimaksudkan untuk memperlihatkan bahwa dua atau lebih kelompok data sampel berasal dari populasi yang memiliki variansi yang sama. Pada analisis regresi, persyaratan analisis yang dibutuhkan adalah bahwa galat regresi untuk setiap pengelompokan berdasarkan variabel terikatnya memiliki variansi yang sama. 


\section{KESIMPULAN}

Gel ekstrak metanol bunga kecombrang (Etlingera elatior) memiliki aktivitas antibakteri terhadap bakteri Staphylococcus aureus dan Staphylococcus epidermidis.

\section{DAFTAR PUSTAKA}

1. Sukandar, D., Radiastuti, N., Jayanegara, I., Hudaya, A. 2010. Karakteristik Senyawa Aktif Antibakteri Ekstrak Air Bunga Kecombrang (Etlingera elatior) Sebagai Bahan Pangan Fungsioanal. Valensi Vol. 2 No. 1.

2. Tampubolon, O.T., S. Suhatsyah, dan S. Sastrapradja. 1983. Penelitian Pendahuluan Kimia Kecombrang (Nicolaia speciosa Horan). Risalah Simposium Penelitian Tumbuhan Obat III. Farmasi, UGM, Yogyakarta.

3. Ansel, Howard C. 1989. Pengantar Bentuk Sediaan Farmasi. UI-Press: Jakarta.

4. Herdiana, Y. 2007. Formulasi gel Undesilenil Fenilananin dalam aktivitas sebagai pencerah kulit. Karya ilmiah. Fakultas Farmasi Unpad Jatinagor.

5. Martin, A.J.S., Swarbrick, dan Cammarata, A. 1993. Farmasi Fisika. Edisi 3, diterjemahkan oleh Yoshita. UI-Press. Jakarta.

6. Rowe, R. C., Sheskey, P. J., and Quinn, M. E. 2009. Handbook of Pharmaceutical Excipients. Sixth Edition. Pharmaceutical Press. London.

7. Anonim. 1979. Farmakope Indonesia. Edisi Ketiga. Dapertemen Kesehatan Indonesia. Jakarta.

8. Mpila, D.A., Fatimawali, dan Wiyono, W.I. 2012. Uji Aktivitas Antibakteri Ekstrak Etanol Daun Mayana (Coleus atropurpureus [L] Benth) terhadap Staphylococcus aureus, Escherichia coli DAN Pseudomonas aeruginosa Secara In-vitro. FMIPA UNSRAT. Manado. 